\title{
Specific cutting energy variations under different rice stem cultivars and blade parameters
}

\author{
Variaciones en la energía específica de corte según las características \\ del tallo de arroz y los parámetros geométricos del par cortante
}

\author{
Alireza Allameh ${ }^{*}$ and Mohammad Reza Alizadeh ${ }^{1}$
}

\begin{abstract}
Cutting energy requirement for rice stem is a momentous touchstone in design or optimization of cutting mechanism on harvesting machines. Various parameters such as physical and mechanical properties of a plant stem and blade shearing components are effective on the cutting energy requirement. Specifying these parameters and their impacts on the cutting energy would be especially important in the assessment of each cutting mechanism efficiency and total energy utilization. In this study, using a test-rig pendulum displacement cutting apparatus, specific cutting energy for single stem cutting of rice stem was identified. The experiments were analyzed in a factorial arrangement laid out in a completely randomized design (CRD) with three replications in order to examine the effects of rice cultivars (at four levels: Hashemi, Ali Kazemi, Fajr, and Khazar), cutting angle (at three levels: 25, 30, and 35 degrees), blade bevel angle (at four levels: 25, 30, 35, and 40 degrees), and blade speed (at three levels: 1.5, 2.0, and $\left.2.5 \mathrm{~m} \mathrm{~s}^{-1}\right)$ on the specific cutting energy for rice stem. The results revealed that rice cultivar and blade velocity had significant effects $(\mathrm{P}<0.01)$ on the specific cutting energy. There were significant differences among cultivars in the view of specific cutting energy so that the highest and lowest values belonged to Hashemi $\left(29.29 \mathrm{~kJ} \mathrm{~m}^{-2}\right)$ and Khazar $\left(16.81 \mathrm{~kJ} \mathrm{~m}^{-2}\right)$, respectively. When blade velocity increased from $1.5 \mathrm{~m} \mathrm{~s}^{-1}$ to $2.5 \mathrm{~m} \mathrm{~s}^{-1}$, specific cutting energy raised about $77 \%$. Blade cutting and bevel angles were not solely influential on the specific cutting energy but they interacted with rice cultivar and impacted it. Optimum specific cutting energy obtained at cutting and blade bevel angles of 30 and 30 degrees, respectively.
\end{abstract}

Key words: specific cutting energy, rice stem, cutting angle, bevel angle.

\section{RESUMEN}

La energía específica de corte necesaria para segar el tallo de arroz es un requisito fundamental al momento de diseñar u optimizar las propiedades mecánicas de una máquina cosechadora de granos. Las propiedades físicas y mecánicas del tallo así como la influencia de los parámetros geométricos y cinemáticas del par cortante (cuchilla/sufridera) son componentes efectivos para determinar esta energía. Especificar estos parámetros y su impacto en la energía de corte es fundamental para evaluar la eficiencia de cada mecanismo de corte y la energía total utilizada. En este estudio se utilizó una prueba de péndulo con desplazamiento de los componentes de corte para calcular la energía específica de corte de un tallo de arroz. El diseño experimental fue factorial completamente al azar con tres repeticiones con el objetivo de evaluar los efectos de cultivares de arroz (en cuatro niveles: Hashemi, Ali Kazemi, Fajr, y Khazar), ángulo de corte (en tres niveles: 25, 30 y 35 grados), el ángulo de bisel de la hoja (en cuatro niveles: 25, 30, 35 y 40 grados), y velocidad de la hoja (en tres niveles: 1,5; 2,0 y 2,5 $\mathrm{m} \mathrm{s}^{-1}$ ) en la energía específica de corte para tallo del arroz. Los resultados revelaron que cultivar de arroz y la velocidad de la cuchilla tuvieron efectos significativos $(P<0,01)$ en la energía de corte específica. Hubo diferencias significativas entre cultivares en la energía específica de corte donde el valor más alto y más bajo se observaron en Hashemi $\left(29,29 \mathrm{~kJ} \mathrm{~m}^{-2}\right)$ y Khazar $\left(16,81 \mathrm{~kJ} \mathrm{~m}^{-2}\right)$, respectivamente. Al aumentar la velocidad de la cuchilla de 1,5 $\mathrm{m} \mathrm{s}^{-1}$ a 2,5 $\mathrm{m} \mathrm{s}^{-1}$, la energía específica de corte se elevó alrededor del 77\%. Los ángulos de corte y bisel no solo influyeron en la energía de corte, además interactuaron con el cultivar de arroz y lo afectaron. La óptima energía específica se obtuvo con ángulos de corte y bisel de $30^{\circ}$, en ambos casos.

Palabras clave: energía específica de corte, tallo del arroz, el ángulo de corte, ángulo de bisel.

1 Rice Research Institute of Iran, Agricultural Research, Education and Extension Organization (AREEO). Rasht, Iran.

* Corresponding author: arallameh@yahoo.com or a.allameh@areo.ir

Fecha de Recepción: 30 Octubre, 2015.

Fecha de Aceptación: 15 Julio, 2016.

DOI: $10.4067 /$ S0718-34292016005000024 


\section{Introduction}

Rice harvesting machines (i.e., reapers and combines) are commonly equipped with reciprocating cutting mechanism. In this case, a cutting bar has some knives and counter edges which move against each other. If plants stem stands between them, it is cut due to reciprocating movement of knife or both knife and counter edge. Relative performance of cutting elements on harvesting mechanisms can be judged by cutting energy requirement, shearing force, and applied stress. Chancellor (1988) suggested that, in harvesters equipped with a reciprocating cutter bar, shear was responsible for cutting of cereal and forage crops and took about 65 percent of the total energy, 25 percent of which was spent in compression and the rest in bending the plants.

Some researchers have studied the effects of various variables in the process of cutting agricultural crops and expressed that force and energy parameters laid in relatively restricted ranges for cutting of these materials. At first, these variables are affected by the properties of measuring instruments by which these measurements are accomplished. Nonetheless, the observed values for cutting energy in the lab were slightly less than those obtained in the field for crop harvesters (Chancellor, 1988).

Pendulum displacement method is the most commonly used approach for precise measurement of dynamic cutting energy in Joules which has been utilized by researchers for cereal, pulses, and forage crops. Yore et al. (2002) investigated stem cutting properties of two rice varieties to assist development of new platform systems for combine. The average force and cutting energy were measured by means of dual knives cutting mechanism like a combine. Treatments included single stem and multi stems. They found out that cutting energy per stem reduced when the number of stems cut at the same time increased. They reasoned that it was partly due to the sensitivity of cutting force to the place of stem nodes and the rest related to the failure mode when multiple stems were cut.

Yiljep \& Mohammad (2005) studied cutting energy of sorghum stalk using a pendulum displacement device. A knife having blade bevel angle of 30 degree and blade velocities up to $8.5 \mathrm{~m} \mathrm{~s}^{-1}$ were considered for experiments. The results showed that blade velocity, cutting energy required, and cutting efficiency were highly correlated $(P \geq 0.1)$. Blade velocities of 3.5 and $5.75 \mathrm{~m} \mathrm{~s}^{-1}$ for ground level and at the height of $120 \mathrm{~mm}$ cutting were optimum with the minimum cutting energies as 9.5 and $6.0 \mathrm{~N} \mathrm{~m}^{-1}$, respectively. The maximum cutting efficiencies at cutting velocities of 5.2 and $7.3 \mathrm{~m} \mathrm{~s}^{-1}$ were achieved for ground level and at the height of $120 \mathrm{~mm}$ cutting, respectively.

Alizadeh et al. (2011) conducted experiments to evaluate cutting energy at different internodes of rice stem. Their results revealed that cutting energy was significantly $(\mathrm{P}<0.01)$ affected by internodes place and dimensional properties of rice stem. They stated that by increasing cutting height, lower energy would be consumed by machine.

The determination of the cutting energy required for rice stem is an important criterion in evaluation of each cutting system. Various parameters such as physical and mechanical properties of the stem and blade components are effective on the cutting energy. These parameters and their impacts on the cutting energy have special importance in the design and optimization of a cutting mechanism. Therefore, this study aimed to determine the specific cutting energy required for a single stem of rice and study physical properties of the stem and the effects of different blade parameters on the specific cutting energy.

\section{Materials and Methods}

This study was conducted over four rice cultivars planted at the research station of Rice Research Institute of Iran (RRII), Rasht, Iran, during cropping season of 2013-2014. Utilized cultivars included as Hashemi and Ali-Kazemi (local cultivars), and Khazar and Fadjr (improved cultivars). Rice stem samples were obtained from the plots having uniform growth. At the maturity, the samples were randomly chosen and manually cut by a sickle at the ground-level. Then, they were transferred to the laboratory for further tests at that day.

In order to measure the cutting energy, a test-rig pendulum displacement apparatus was designed and fabricated (Figure 1). This device consisted of three main parts including: pendulum set, angle pointer, and chassis. When pendulum arm is unhanded from a given height, it passes against a counter edge in a given velocity and cut the stem held standing in front of the counter edge.

To do cutting experiments, blades with three cutting angles of 25,30 , and $35^{\circ}$ and four bevel angles of $25,30,35,40^{\circ}$ were employed. It should be noted that stem cutting took place at the height of about 


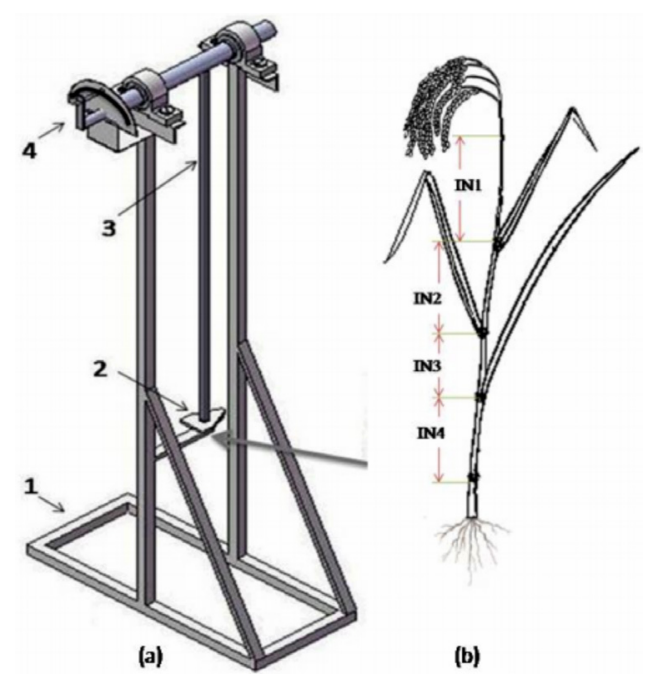

Figure 1. Schematic diagram of the pendulum displacement apparatus 1- Chassis; 2- Cutting blade; 3- Pendulum arm; 4- Angle pointer).

$20 \mathrm{~cm}$ (IN4, Figure 1b) from the ground base as it was done at the field in the mechanized harvesting.

Following formulas were used for calculation of the cutting energy and blade velocity at cutting point (Alizadeh et al., 2011):

$$
\begin{gathered}
\mathrm{E}_{\mathrm{c}}=\operatorname{MgR}\left(\operatorname{Cos} \theta_{3}-\operatorname{Cos} \theta_{2}\right) \\
\mathrm{V}_{\mathrm{c}}=\omega \mathrm{L}=\sqrt{\frac{2 \mathrm{MgR}\left(1-\operatorname{Cos} \theta_{1}\right)}{\mathrm{I}}} \times \mathrm{L}
\end{gathered}
$$

In which,

$\mathrm{E}_{\mathrm{c}}$ : cutting energy, $\mathrm{kJ}$

$\mathrm{M}$ : mass of pendulum arm with blade, $\mathrm{kg}$

g: gravity constant $=9.8 \mathrm{~m} \mathrm{~s}^{-2}$

$\mathrm{R}$ : distance of rotation center from gravity center of pendulum arm, $\mathrm{m}$

$\theta_{1}$ : initial angle of pendulum arm when lifted, radian

$\theta_{2}$ : angle of pendulum arm without cutting a stem, radian

$\theta_{3}$ : angle of pendulum arm after cutting a stem, radian

$\omega$ : angular velocity of the blade at cutting moment, radians $\mathrm{s}^{-1}$

I: moment of inertia for pendulum arm set, $\mathrm{kg}$ $\mathrm{m}^{-2} \mathrm{rad}^{-2}$

L: distance between blade center and rotation axis, $m$

$\mathrm{V}_{\mathrm{c}}$ : linear velocity of the blade at cutting point, $\mathrm{m} \mathrm{s}^{-1}$
Figure 2 illustrates pendulum arm at different positions (A: equilibrium mode; B: arm lifted stored potential energy; $\mathrm{C}$ : no cutting mode; D: cutting mode).

In this research, rice stem was considered as a narrow-wall hollow cylinder with an elliptical cross section. All stem dimensions were measured by a digital slide caliper (Mitutoya Caliper, Japan) with an accuracy of $0.01 \mathrm{~mm}$. The following formula was used (Alizadeh et al., 2011):

$$
\mathrm{A}=\frac{\pi \mathrm{t}(\mathrm{a}+\mathrm{b}-2 \mathrm{t})}{2}
$$

In which,

A: stem cross sectional area, $\mathrm{m}^{2}$

$\mathrm{a}$ and $\mathrm{b}$ : major and minor diameters, $\mathrm{m}$

t: stem thickness, $\mathrm{m}$.

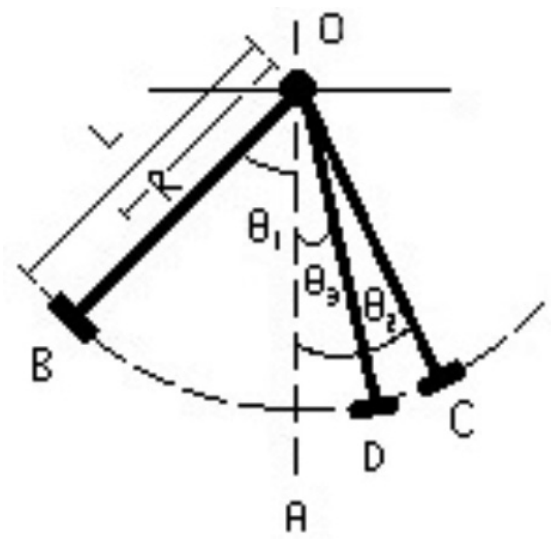

Figure 2. Schematic representation of pendulum arm at different positions.

In order to simulate cutting, a single stem was held vertically between two jaws of a clamp and fastened by a bolt to a stand. Inner faces of the jaws had been covered with a soft and flexible tissue so that stems were not damaged. Then, the clamp was kept right-angled in front of the ledger plate. Unhanding pendulum arm from an initial height, blade traversed its route and consumed part of its stored energy to cut the stem and went up to a height less than initial. This final height was recorded by angle pointer as $\theta_{3}$.Inserting all values into the equation (1), cutting energy required for that stem would obtain. Since cutting energy varies with respect to cross sectional area of every single stem, the specific cutting energy is used as a standard (Kronbergs et al., 2012): 


$$
\mathrm{E}_{\mathrm{sc}}=\frac{\mathrm{E}_{\mathrm{c}}}{\mathrm{A}}
$$

In which,

$\mathrm{E}_{\mathrm{sc}}$ : specific cutting energy, $\mathrm{kJ} \mathrm{m}^{-2}$

$\mathrm{E}_{\mathrm{c}}$ : cutting energy, $\mathrm{J}$

A: stem cross sectional area, $\mathrm{m}^{-2}$

At last, complete randomized design (CRD) was laid out in a factorial arrangement with three replications to assess the effects of different parameters on the cutting energy requirement. Independent variables consisted of rice cultivars at four levels (Hashemi, Ali-Kazemi, Fadjr, and Khazar), cutting angle at three levels $(25,30$, and $\left.35^{\circ}\right)$, blade bevel angle at four levels $(25,30,35$, $40^{\circ}$ ), and blade velocity at three levels (1.5, 2.0, $2.5 \mathrm{~m} \mathrm{~s}^{-1}$ ). Data analysis took place using SAS 9 (2004, SAS Institute, US) and Microsoft EXCEL software's (2010, Microsoft Corporation, US).

\section{Results and Discussion}

\section{The effect of cultivar}

Specific cutting energy for tested cultivars in an identical condition (cutting angle of $25^{\circ}$, bevel angle of $25^{\circ}$, and blade velocity of $1.5 \mathrm{~m} \mathrm{~s}^{-1}$ ) has been shown in Figure 3. It can be seen that cultivars of Hashemi and Khazar have had the highest and lowest specific cutting energy, respectively.

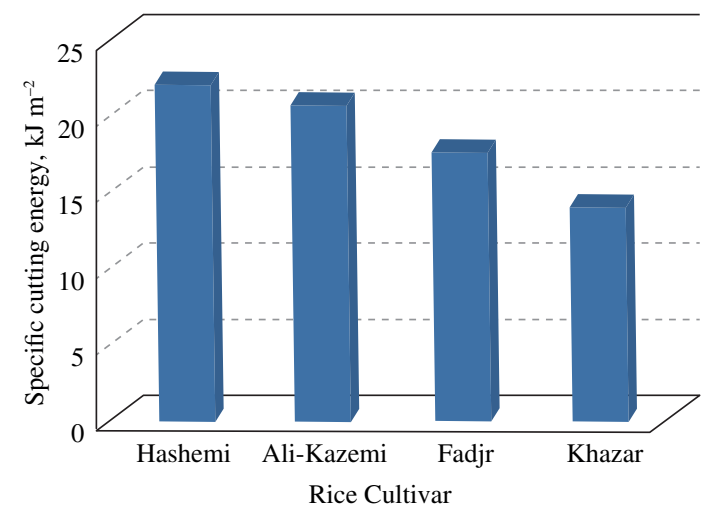

Figure 3. Specific cutting energy of cultivars at an identical test condition.

In Table 1, it is represented that cultivars of Khazar and Fadjr as improved cultivars have had the lowest specific cutting energy compared to local cultivars of Hashemi and Ali-Kazemi, respectively. Such significant differences arise mainly from different physical and physiological characteristics of local and improved cultivars. Figure 4 shows the average values of stem cross sectional areas for examined cultivars. It reveals that the average cross sectional area of Khazar's stem is roughly 1.9, 1.7, and 1.17 times greater than Hashemi, AliKazemi, and Fadjr cultivars, respectively. Although much more shearing force is required for cutting Khazar's stem, its specific cutting energy is lower than the others because of having greater stem cross sectional area as described in Equation 4.

Table 1. Means comparison for specific cutting energy of rice stem.

\begin{tabular}{lc}
\hline Cultivar & Specific cutting energy, $\mathrm{kJ} \mathrm{m}^{-2}$ \\
\hline Hashemi & $29.29^{\mathrm{a}}$ \\
Ali-Kazemi & $24.51^{\mathrm{b}}$ \\
Fadjr & $21.75^{\mathrm{c}}$ \\
Khazar & $16.81^{\mathrm{d}}$ \\
\hline
\end{tabular}

There is no significant difference among means having common letters.

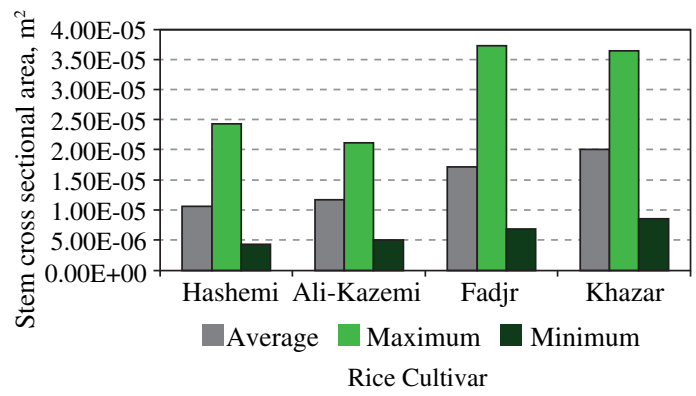

Figure 4. Stem cross sectional area of tested cultivars.

By increasing cross sectional area, contact area between blade and stem and as a consequent the required force for cutting stem will increase. According to equation 4, as stem cross sectional area decreases, specific cutting energy increases. In other word, a reverse relationship exists between the cross sectional area and the specific cutting energy. This has been reported by other researchers (McRandal \& McNulty, 1978; Rajput \& Bhole, 1973; Igathinathan et al., 2010; Alizadeh et al., 
2011). Investigations express that shearing strength of improved varieties are greater than that of local varieties. As a reason, it can be noted that improved varieties have more dense and voluminous stems in comparison with local ones (Lee \& Yan, 1984; Tabatabaee-Koloor et al., 2004).

\section{The effect of blade velocity}

Means comparison illustrates that within different blade velocities, values for specific cutting energy of the stem have significant difference $(\mathrm{P}<0.01)$ with each other. When blade velocity went up from 1.5 to $2.5 \mathrm{~m} \mathrm{~s}^{-1}$, specific cutting energy increased about $77 \%$ (Table 2). The variations of specific cutting energy have been represented for cutting angle of $35^{\circ}$ and bevel angle of $35^{\circ}$ in Figure 5.

Table 2. Means comparison for specific cutting energy of rice stem in different blade velocities.

\begin{tabular}{cc}
\hline Blade velocity $\left(\mathrm{m} \mathrm{s}^{-1}\right)$ & Specific cutting energy $\left(\mathrm{kJ} \mathrm{m}^{-2}\right)$ \\
\hline 1.5 & $16.47^{\mathrm{c}}$ \\
2.0 & $23.53^{\mathrm{b}}$ \\
2.5 & $29.27^{\mathrm{a}}$ \\
\hline
\end{tabular}

There is no significant difference among means having common letters.

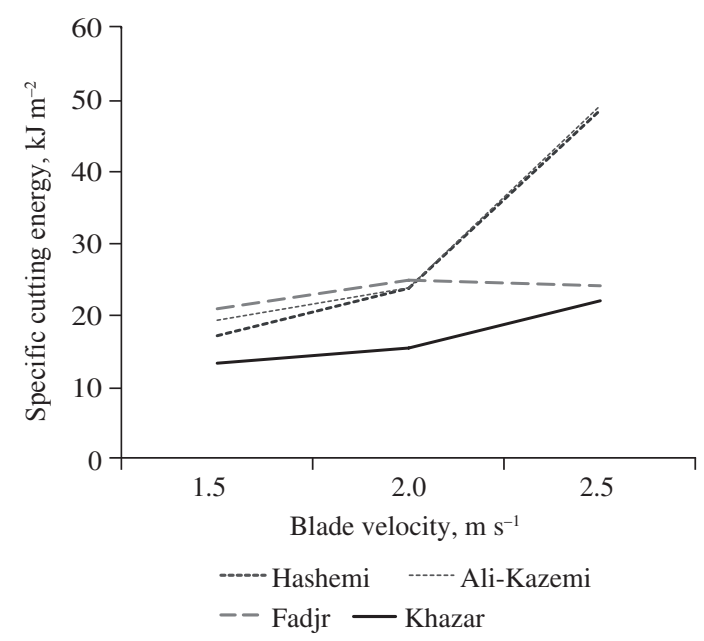

Figure 5. A typical trends for specific cutting energy in terms of blade velocities.

In the experiments, stems were firmly kept by a clamp opposite to the ledger plate so that there was no way they could run away alongside the blade. Also, because of being serrated, the coefficient of friction between the blade edge and the stem increased and within lower speeds, stem gliding over blade edge minimized. By increasing blade velocity, cutting process would occur in a shorter time. Therefore, this extra energy would be taken to accelerate cut parts of a stem and they would be thrown much farther. This has been reported by the others (Prasad \& Gupta, 1975; Yiljep \& Mohammad, 2005; Johnson et al., 2012).

\section{The interaction of cultivar and blade velocity}

In this study, it was realized that the selected velocities were over critical limit. The higher blade velocity at cutting point, the more kinetic energy will apply to the stem. Since actual energy requirement for cutting a stem was less than those applied, a great amount of kinetic energy would be lost so as to accelerate cut part of the stem and throw it farther away. Srivastava et al. (2007) expressed that acceleration of the stem at cutting point had a direct relation with square of blade velocity at cutting moment and an indirect relation with the diameter of the stem. Similar reports have been mentioned by the others (Chattopadhyay \& Pandey, 2001; Yiljep \& Mohammad, 2005; Johnson et al., 2012).

\section{The interaction of cultivar, cutting angle, and blade velocity}

It was observed that by increasing blade velocity at a given cutting angle for every single cultivar, specific cutting energy went up (Figure 6). To a great extent, this is attributed to physical and mechanical characteristics of a rice stem while blade parameters are interacted with them. In a beveled cutting, resisting force decreases since shearing occurs gradually. In other words, the stem is not cut at once but shearing completes progressively (Srivastava et al., 2007). The lesser cutting angle, the more blade edge compresses the stem and causes its bending (Chakraverty et al., 2003). Local cultivars, like Hashemi, characterize with low shearing strength stems in comparison with improved ones (Tabatabaee-Koloor et al., 2004). By decreasing cutting angle, the stem will be bent alongside the applied force. Therefore, more energy is taken in order to complete shear. However, such a condition was not observed for 

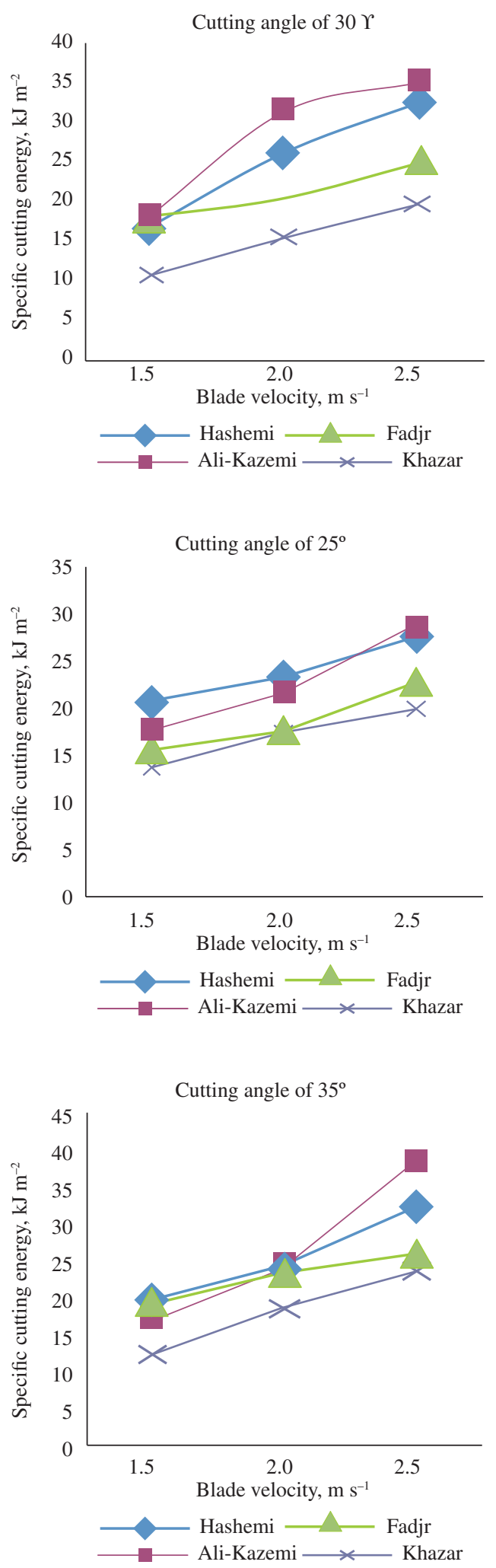

Figure 6. Specific cutting energy at different cutting angles. high yielding cultivars (Fadjr and Khazar) due to their high shearing strength. Igathinathane et al. (2010) stated that total cutting energy related to nodes and internodes had significant variations in terms of stem cross sectional area. The results of a study demonstrated that specific cutting energy had a direct relation to cutting velocity and cutting energy was proportional to the stem diameter (Johnson et al., 2012).

\section{Conclusion}

Rice cultivars and blade velocity had significant effect $(\mathrm{P}<0.01)$ on the specific cutting energy. Blade cutting and bevel angles did not individually affect the specific cutting energy but their interactions could influence it significantly. Local cultivars showed higher specific cutting energy than improved ones due to smaller cross sectional area. Tested blade velocities were higher than critical limit so that by increasing velocity, energy was wasted as carrying cut stem farther away.

\section{Acknowledgment}

This work was extracted from a research project approved and supported by Rice Research Institute of Iran (RRII) under registration $\mathrm{N}^{\circ}$ 2-012-130000-14-0000-83015. The authors would like to express their gratitude for financial assistances.

\section{Literature Cited}

Alizadeh, M.R.; Rahimi-Ajdadi, F.; Dabbaghi, A. 2011. Cutting energy of rice stem as influenced by internodes' position and dimensional characteristics of different varieties. Australian J of Crop Sci 5 (6): 681-687.

Datta, A.C.

2003. Harvesting and threshing. In: Chakraverty, A.; Mujundar, A.S.; Raghavan, G.S.V.; Ramaswamy, H.S. (ed.) Handbook of postharvest technology. $1^{\text {st }}$ ed., Marcel Dekker Inc., New York, US. pp. 57-116.

Chancellor, W.J.

1988. Cutting of biological materials. In: Brown, R.H ed. Handbook of Engineering in Agriculture. Vol. 1. CRC Series in Agriculture, Boca Raton, FL: CRC Press, pp. 33-63.

Chattopadhyay, P.S.; Pandey, K.P.

2001. Impact cutting behavior of sorghum stalk using a flail cutter - a mathematical model and its experimental verification. Journal of Agricultural Engineering Research, 78 (4): 369-376.

Igathinathane, C.; Womac, A.R.; Sokhansanj, S.

2010. Corn stem orientation effect on mechanical cutting. Biosystems Engineering, 107: 97-106. 
Johnson, P.C.; Clementson, C.L.; Mathanker, S.K.; Grift, T.E.; Hansen, A.C.

2012. Cutting energy characteristics of Miscanthus $x$ giganteus stems with varying oblique angle and cutting speed. Biosystems Engineering, 112 (1): 42-48.

Kronbergs, A.; Kronbergs, E.; Siraks, E.; Dalbins, J.

2012. Cutting properties of arranged stalk biomass. Renewable Energy and Energy Efficiency, 2012 - Conditioning of the energy crop biomass compositions, pp. 145-149.

Lee, S.W.; Yan, H.

1984. Threshing and cutting forces for Korean rice. Transaction of the ASAE, 16: 1654-1657.

McRandal, D.M.; McNulty, P.B.

1978. Impact cutting behavior of forage crops II. Field tests. Journal of Agricultural Engineering Research, 23 (3): 329-338.

Prasad, J.; Gupta, C.P.

1975. Mechanical properties of maize stalk as related to harvesting. Journal of Agricultural Engineering Research, 20 (1): 79-87.
Rajput, D.S.; Bhole, NG.

1973. Static and dynamic shear properties of paddy stems. Harvester, 4: 17-21.

Srivastava, A.K.; Georing, C.E.; Rohrbach, R.P.; Buckmaster, D.R. 2007. Hay and forage harvesting. In Engineering Principles of Agricultural Machines. $2^{\text {nd }}$ ed. St. Joseph, Michigan: ASABE. $559 \mathrm{p}$

Tabatabaee-Koloor, R.; Borghaei, A.; Allameh, A.

2004. Investigating the effects of variety and blade parameters on shear strength of rice stem related to harvesting. Proc Ag Eng conf, K U Leuven, Belgium.

Yiljep, Y.D.; Mohammad, U.S.

2005. Effect of knife velocity on cutting energy and efficiency during impact cutting of sorghum stalk. Agric. Eng. Intl.: the CIGR E-Journal, 7 (4).

Yore, M.W.; Jenkins, B.M.; Summers, M.D.

2002. Cutting properties of rice straw. ASAE Meeting Paper $\mathrm{N}^{\circ}$ 026154. St. Joseph, Michigan, 49085-9659. 
